\title{
Cropping in Semi-arid Northwest India in Greenhouse with Ground Coupling Shading and Natural Ventilation for Environmental Control
}

\author{
Girja Sharan \\ DA Institute of Information and Communication Technology \\ Gandhinagar \\ girja_sharan@daiict.ac.in \\ T. Madhavan \\ Indian Institute of Management \\ Ahmedabad \\ madhavan@,iimahd.ernet.in
}

\begin{abstract}
Research is ongoing to develop greenhouse technologies which economically control water and energy in order to improve farming in water-scarce, hot, semi-arid regions of north-west India. A greenhouse under investigation was coupled to earth-tubeheat-exchangers (ETHE) and also had provisions for shading, natural ventilation and mist nozzles. Tomatoes were grown in the greenhouse. In the cooler months, a regime of natural ventilation and top shading kept the greenhouse temperature close to ambient temperature. Mist was not used. Evaporation and later transpiration may have aided cooling. This cooling effort became less effective in warmer periods as the cooling load increased and dense foliage appeared to hinder ventilation. Forced ventilation via ETHE and top shading was then implemented. Inside temperature occasionally rose $2-3{ }^{\circ} \mathrm{C}$ above the ambient temperature. Cropping could be done through the spring and early summer. Heating was affectively achieved with ETHE in cold nights of December and January keeping the inside temperatures well above $12^{\circ} \mathrm{C}$. Yields were $68 \mathrm{t} / \mathrm{ha}$ - nearly twice the open field production, while the water used $(266 \mathrm{~mm})$ was nearly half of the open-fields usage. This appears to be a promising new way to improve livelihoods from farming.
\end{abstract}

Index Terms- Earth-tube-heat- exchanger, greenhouse, semi- arid areas, India

\section{INTRODUCTION}

The Kutch region of north-west India (68.3 to $72.5 \mathrm{E}, 22.5$ to $24.5 \mathrm{~N}$ ), spreads over 45,000 sq $\mathrm{km}$, is semi-arid, and is characterized by a wide occurrence of salt-affected soils and poor quality water. It is bordered in the west by the Arabian Sea and in the north by the Great Rann of Kutch - a barren expanse of salt-crusted ground vacated by recession of sea. Rainfall is low (mean 300 $\mathrm{mm}$, coefficient of variation $60 \%$ ), while ambient temperatures are high $\left(>31^{\circ} \mathrm{C}\right.$ in all months, summer $>35^{\circ} \mathrm{C}$ ). Cropping is carried out in areas where groundwater is still suitable. Excessive withdrawal and inadequate recharge is rapidly depleting these aquifers making surface irrigation with conventional methods expensive and unsustainable. In most parts groundwater is not suitable for direct use. As a result, vast tracts remain uncultivated. Livelihoods from farming have always been difficult due to low and unstable yields. Despite awareness that open-field 
agriculture places great burdens on water resources, there has been little research on possible alternatives ${ }^{15}$. Despite an adverse climate, arid areas do have natural resources such as high radiation levels and long sunshine hours which signify productive potential. Deep soil can be both a source and a sink for low temperature heat. Moisture laden winds near coast can be a source of moisture.

Elsewhere, in similar climates, (the Middle East, south-western US, parts of Spain) adoption of protected and covered cultivation has led to higher productivity. Mears ${ }^{9}$ pointed to similar possibilities specifically for arid regions of India. He stated that "while a greenhouse is generally regarded as necessary to provide a warm environment in cold climates, it has also been shown that with properly designed cooling systems, it is possible to improve plant growing conditions under extensively hot conditions. Adaptation of modern cooling technologies to Indian conditions will undoubtedly lead to increased opportunities for production of high value plants and materials in areas where the environment is extremely harsh. Protected cultivation also has the potential benefit of substantially increasing plant productivity per unit water consumption, which is important in many areas where good quality water is severely limited. AlJamal $^{1}$, working in Jordan, stated that "a GH (greenhouse) is required for agricultural production in most hot countries during summer period. Water consumption used for a $\mathrm{GH}$ is much less than water required in open agriculture. A GH can also be used during the winter by utilizing solar energy for heating." Greenhouse technology in India is focused on colder regions. Adequate research has not been carried out to adapt it to hot, semi-arid and arid areas. With that in view, a comprehensive R\&D program was initiated in 1998 by the Centre for Management in Agriculture, Indian Institute of management, Ahmedabad. A new R\&D centre was established inside Kutch at Kothara ( $\left.23^{\circ} 14 \mathrm{~N}, 68^{\circ} 45 \mathrm{E}\right)$ to develop greenhouse technology specially adapted to local conditions.

It was recognized that lack of good quality water as well as adequate environmental controls in such climates - are the two largest challenges. A two phase program was planned. The goal of the first phase was to develop a greenhouse for those parts that have relatively better quality water, focusing the R\&D on development of suitable environmental control measures. In the second phase it was planned to address the problem of desalination of brackish groundwater so that greenhouse cultivation can later be extended to areas where water is of poor quality. In this paper the work done on the environmental control measures is presented. In addition to the engineers employed in the project, 5 to 6 undergraduate agricultural engineers regularly worked with the team as summer interns each year. The project now regularly hosts engineer-interns. The first section is a review of the literature related to environmental controls of greenhouses in hot areas, followed by a description of the steps undertaken to develop a greenhouse coupled to an earth-tube-heat-exchanger with provisions for other measures. Finally, the result of growing tomatoes is discussed. Some important insights that emerged in the course of the work are included in the last section. These included the importance of direct observation as a means of identifying real problems, building partnerships for achieving results, and benefits accruing to society are included in the last section.

\section{LITERATURE REVIEW}

The temperature rise inside an unventilated, well watered, greenhouse can be computed using $\mathrm{Kittas}^{6}$, expression as, 


$$
\Delta \mathrm{T}=\frac{0.017 \mathrm{~K}+2.64}{1+0.085 \mathrm{u}^{0.08}}
$$

Where:

$\begin{array}{lll}\Delta T & = & \text { temperature difference between greenhouse inside and ambient }\left({ }^{\circ} \mathrm{C}\right) \\ K & = & \text { global irradiance outside greenhouse }\left(w / \mathrm{m}^{2}\right) \\ u & = & \text { wind velocity measured at } 4 \text { m above ground }(\mathrm{m} / \mathrm{s}) \\ R & = & \text { renewal (air change rate) per hour } \\ K_{\max } & =\quad \text { maximum global irradiance }\left(w / \mathrm{m}^{2}\right)\end{array}$

The temperature difference, $\Delta \mathrm{T}$, computed with global solar irradiance at noon (12:00) and mean day time wind velocities measured at a height close to $4 \mathrm{~m}$ at Kothara, is shown in column (3) of Table (1). In December, when day temperatures are typically near $32^{\circ} \mathrm{C}$, an unventilated greenhouse will be hotter by $14{ }^{\circ} \mathrm{C}$, or at $46^{\circ} \mathrm{C}$. The difference will be larger in other months; for example, spring $\left(16^{\circ} \mathrm{C}\right)$, summer $\left(17^{\circ} \mathrm{C}\right)$ and in fall $\left(15-17^{\circ} \mathrm{C}\right)$. The temperature range for good growth in general is $18-30^{\circ} \mathrm{C}$. For tomatoes, one of the popular greenhouse crops in many places, the temperature range is $12-32^{\circ} \mathrm{C}$. Greenhouses will be overheated at all times without effective cooling. Natural ventilation is a simple solution requiring no energy. Shading is another simple solution which should be considered. Wind speeds are generally high in the region especially near the coast; and higher during the day - particularly in the hot seasons, spring and summer. Natural ventilation can be expected to affect high renewal rates (air changes per unit time), perhaps close to 40 per hour. In other words, the total volume of air contained in greenhouse is changed or renewed forty times in an hour. With such a renewal rate, $\Delta \mathrm{T}$ will be reduced and can be computed by another expression by Kittas ${ }^{7}$.

$$
\mathrm{R}=\frac{0.31 \mathrm{~K}_{\max }}{\Delta \mathrm{T}}
$$

The temperature difference $(\Delta \mathrm{T})$ is reduced to $5-6{ }^{\circ} \mathrm{C}$ in winter and $7{ }^{\circ} \mathrm{C}$ in summer months (column 5). A closed greenhouse, without any measure of control, is usually at the same temperature as the ambient air at night. During the day, with natural ventilation, temperature will be above ambient by $\Delta \mathrm{T}$. The range of temperature that will prevail inside the greenhouse is shown in column 6. Natural ventilation is popular in the Mediterranean regions ${ }^{7}$ and promises to be effective in this region also, but as seen from column 6, under conditions that prevail in Kutch region, it is only in December that this measure will be keep the inside temperature from exceeding $32{ }^{\circ} \mathrm{C}$. In all other months, further cooling measures will be needed to reduce inside temperature to this level owing to the high heat load in the region. Heating requirements in the region are limited to nights in December to February.

Cladding is the first barrier against entry of radiation into greenhouses thereby reducing the cooling load. Kittas et al. ${ }^{8}$ reported that in the waveband $300-1100 \mathrm{~nm}$, total transmission of irradiance into a polythene covered tunnel was 0.65 , and using twin span glass house it was 0.54 . Using multi-span fiberglass house it was 0.49. Shading devices can further alleviate heat load. When the glass house was shaded with a black mesh plastic net of $30 \%$ shading, the total transmission reduced to 0.401 and more dramatically to 0.171 with an aluminized shade screen of 
$70 \%$ shading. They showed by detailed measurements that devices may not be waveband-neutral and their effect also has a qualitative dimension.

TABLE I

TEMPERATURE RISE IN UNVENTILATED AND NATURALLY VENTILATED GREENHOUSE UNDER CONDITIONS OF KUTCH REGION

\begin{tabular}{|c|c|c|c|c|c|c|}
\hline Month & $\begin{array}{l}\text { Global } \\
\text { solar } \\
\text { irradiance } \\
\text { at noon }\end{array}$ & $\begin{array}{l}\text { Mean } 4 \\
\text {-m wind } \\
\text { velocity } \\
\text { during } \\
\text { day time }\end{array}$ & $\begin{array}{l}\text { Maximum } \\
\text { temperature } \\
\text { difference - } \\
\text { unventilated } \\
\text { house } \\
\quad \Delta \mathrm{T}\end{array}$ & $\begin{array}{l}\text { temperatur } \\
\text { e difference } \\
\text { with } 40 \text { air } \\
\text { changes/ hr } \\
\Delta \mathrm{T}\end{array}$ & $\begin{array}{l}\text { Expected } \\
\text { greenhouse } \\
\text { minimum } \\
\text { and } \\
\text { maximum } \\
\text { temperatures } \\
\text { With } 40 \\
\text { renewal /hr } \\
\text { natural } \\
\text { ventilation } \\
\quad\left({ }^{\circ} \mathrm{C}\right)\end{array}$ & $\begin{array}{l}\text { Expected } \\
\text { greenhouse } \\
\text { minimum and } \\
\text { maximum } \\
\text { temperatures } \\
\text { With } 50 \% \\
\text { shade and } \\
\text { natural } \\
\text { ventilation } \\
\left({ }^{\circ} \mathrm{C}\right)\end{array}$ \\
\hline January & 725 & 6.1 & 14 & 6 & $8-38$ & $8-34$ \\
\hline February & 781 & 6.4 & 14 & 6 & $9-39$ & $9-35$ \\
\hline March & 883 & 6.6 & 16 & 7 & $17-44$ & $17-39$ \\
\hline April & 914 & 6.4 & 16 & 7 & $20-44$ & $20-39$ \\
\hline May & 952 & 8.7 & 17 & 7 & $21-43$ & $21-38$ \\
\hline June & 962 & 8.5 & 17 & 7 & $20-42$ & $20-37$ \\
\hline July & 658 & 4.5 & 13 & 5 & $25-38$ & $25-35$ \\
\hline August & 842 & 8 & 15 & 7 & $27-35$ & $27-30$ \\
\hline September & 948 & 7 & 17 & 7 & $23-39$ & $23-34$ \\
\hline October & 827 & 5.5 & 15 & 6 & $19-46$ & $19-42$ \\
\hline November & 746 & 5.3 & 14 & 6 & $15-37$ & $15-33$ \\
\hline December & 678 & 5.6 & 13 & 5 & $7-32$ & $7-28$ \\
\hline
\end{tabular}

The black mesh plastic net was reported to be 'perfectly neutral as it maintained the PAR enrichment effect of glass' but aluminized shade screen 'counteracted' that effect. Shading devices have several other effects on greenhouse microclimate as shown by Baille et al. ${ }^{4}$ who studied the effects of white paint (about $8 \mathrm{~kg} \mathrm{CaO}$ per $100 \mathrm{~kg}$ water) over a glasshouse in coastal region of eastern Greece. Average transmission reduced from 0.62 before the paint to 0.31 after. The fluctuation around the mean too reduced due to the fact that paint made the radiation more diffuse. Temperature rises above ambient reduced significantly, so also the vapor pressure deficit of greenhouse air. The canopy became cooler than the air, and canopy-to-air vapor pressure deficit reduced appreciably. The transpiration rate increased by an average of $18 \%$ after paint was applied. The sensible heat flux from the canopy reversed from large positive to a negative value. Crop water stress index reduced especially a few days after whitening. Besides being beneficial to the microclimate, paint as a shading device does not interfere with the ventilation process nor aerodynamics near the cladding as would the nets and screens. 
With a view to select proper shading material for use in Kutch region, Sharan and Chitlange $^{21}$ made radiometric measurement on a set of shade nets marketed in India, in the 400$1000 \mathrm{~nm}$ range at $10 \mathrm{~nm}$ interval. They reported that black and white colored nets provided nearly uniform shading across the waveband. Blue and green nets provided higher shading near their characteristics wavelength and slightly lower than specified elsewhere. Assuming a net of $50 \%$ effective shading is installed over polythene clad greenhouse with transmittance of 0.65 (as in case of Kittas et $\mathrm{al}^{8}{ }^{8}$ ) the overall transmittance will be 0.325 . With such a shade net and natural ventilation, $\Delta \mathrm{T}$ would be lower and accordingly the range of minimum and maximum temperatures reduced, as shown in the last column. Values are obtained using equation (2) with radiation level reduced to one third of that in column (1) and renewals of 40 per hour as before. These two measures would keep the temperature below $32^{\circ} \mathrm{C}$ in August, December; slightly above it in September, November, January and February. This represents a significant improvement. Although, shade nets of higher rating are available, the need to maintain adequate light intensity must also be kept in view.

Now the need for more effective cooling is reduced to six months (March to July) and then in the fall, for which evaporative cooling should be considered. A fan-pad system is the most common means to implement this. Two other options are - sprinkling and fog. In a fan-pad system, water trickles continuously down thick cellulose pads that are installed on one wall of greenhouse. Fans located on the opposite wall pull the ambient outside air through the pads. Some water evaporates by extracting the required heat of vaporization from the air stream, rendering it cooler and more humid. In other words, sensible heat is converted into latent heat. Air can be cooled, at most, to the wet bulb temperature; accordingly its effectiveness is dependent on ambient humidity levels. It will be more effective in arid environments. Air, cooler and more humid near the pad, moves through the growing area absorbing heat and vapor before exiting from the other end. Water draining into the sump below the pads is recycled with replenishment to compensate for water lost. At the stage of planning, information on actual consumption of water in fan-pads was not available for Indian locations. Using the established design procedures (Indian Standard Code as also method outlined by Paul Nelson ${ }^{10}$ ) it was determined that in the hottest part of the year (June), in Kutch area, fan-pads would evaporate at least $7 \mathrm{~mm}$ to $10 \mathrm{~mm}$ of water per day with top shading. This was a deterrent. It was decided not to employ fan-pad in the greenhouse facility that was being envisaged.

It is still difficult to get Indian results on water consumption in fan-pads; but data now available from elsewhere confirms high water consumption. Sabeh ${ }^{13}$ measured water used at Tucson, Arizona. When temperature in a $278 \mathrm{~m}^{2}$ greenhouse growing tomatoes was on automatic control mode maintaining $24^{\circ} \mathrm{C} / 18^{\circ} \mathrm{C}$ day/night temperatures, the cooling system used 14.8 $\mathrm{L} / \mathrm{m}^{2} /$ day of water and crops used $8.9 \mathrm{~L} / \mathrm{m}^{2} /$ day of water. When control was based on a fixed air change rate, less water was consumed but temperature inside was higher. At flow rate of $0.017 \mathrm{~m}^{3} / \mathrm{m}^{2} / \mathrm{s}$ (about 10 air changes per hour) mean temperature inside was $31.1^{\circ} \mathrm{C}$, and water used in cooling $10 \mathrm{~mm}, 16 \%$ higher than the crop. Simulations carried out by Al-Jamal ${ }^{1}$ using a unsteady energy balance model of a polythene clad fan pad cooled greenhouse in Jordan, indicated that with ambient humidity at $10 \mathrm{~g} / \mathrm{m}^{3}$, air change rate of $20 / \mathrm{hr}$ would keep greenhouse in the range of $20-34^{\circ} \mathrm{C}$, and use water at the rate of $4.87 \mathrm{~m}^{3} /$ day or $23 \mathrm{~mm} /$ day. Some other limitations of fan-pad are: "the lack of uniformity of climatic conditions, which are characterized by rising temperature and falling humidity along the length of the structure and in the airflow direction; electric power failure transforms the greenhouse into a heat trap; low cooling effect compared to fogging system; general diminution of efficiency with increasing 
humidity; and waste of water - to prevent blockage of wet pad water bleed is necessary," Arabel et al. $^{3}$. Sprinkling uses large surfaces (blankets) for faster evaporation installed overhead in greenhouses and wetted by mist nozzles. ${ }^{5}$. Air near the surface gets cooled and is moved out by forced ventilation. In a fog system, a large surface is created by turning water into fog (droplets in the range of 2-60 $\mu \mathrm{m}$ ) using very high pressure pump and appropriate nozzles. These droplets fall slowly and are easily carried by air stream. Arabel et al. ${ }^{2}$ made elaborate study of fog system and reported that it provided greater uniformity of temperature and humidity in greenhouse than fan-pad. High water consumption however is the common feature of all forms of evaporative cooling.

It is in this context that the use of earth tube heat exchangers is interesting. ETHE is a device that enables transfer of heat from ambient air to deeper layers of soil and vice versa, via pipes buried into the ground at depths where temperature stays nearly constant or at least the diurnal fluctuations has diminished. Santamouris ${ }^{12}$ reported the experience of coupling the greenhouses to earth-tube-heat-exchanger placed deep into the ground for environmental control. Eighteen greenhouse installations drawn from different countries using ETHE were reviewed. Most were used for supplemental heating and met $28 \%$ to $60 \%$ of the requirement at different places. Actual use in cooling mode, if any, was not mentioned. But using simulated results for a greenhouse facility in Athens $\left(37.5^{\circ} \mathrm{N}\right)$ they stated that ETHE would be an equally attractive supplement for cooling. Air temperature of the greenhouse in summer was predicted and compared with measurements from their $1000 \mathrm{~m}^{2}$ glass-covered greenhouse coupled to a set of four underground parallel pipes made of plastic. The air change rate was not indicated. Simulations showed that continuous ventilation of greenhouse with air from the buried pipes will keep the inside air temperature below $40^{\circ} \mathrm{C}$. Unventilated greenhouse commonly goes up to $45^{\circ} \mathrm{C}$, they stated. Cooling capability of ground coupled systems is limited to the mean temperature of deeper layers of soil in a given place. But the fact that these do not use water and deep ground is a renewable source and sink of energy is interesting.

The above mentioned review led to the following: (a) climatic adversities notwithstanding, semi-arid areas do have features such as high solar radiation and long sunshine hours, which signify potential for high productivity, greenhouse technology is being used successfully in some such regions elsewhere to achieve that potential (b) environmental control, especially cooling, in such areas however is still a challenge; evaporative cooling is most effective, but also one that consumes largest amount of water, comparable or even more than the crop (c) development of control measures that are economical on water and energy would be desirable to successfully actualize via greenhouses the potential for high productivity in hot arid areas. In the context of Kutch region, a satisfactory solution would be one that, besides being economical on water and energy, is easy to maintain and run, able to cope with occasional electricity breakdown. It was decided to build a special greenhouse facility furnished with multiple measures - natural ventilation, shading, ETHE and mist nozzles for occasional supplementary evaporative cooling - and carry out investigations to determine which combination will be effectively address the problem. A R\&D project was started with following objectives.

1. To design and install a greenhouse facility at Kothara, consisting of a greenhouse with multiple measures - natural ventilation, shading, and ETHE and mist nozzles.

2. To carry out investigations to determine the extent to which environmental control is achieved with the use of various measures. Also to determine the extent to which such a 
greenhouse can improve yields of important vegetables crops, conserve water and extend cropping season.

\section{MATERIALS AND METHOD}

Specifications for cladding, shade net, natural ventilation for the greenhouse and other units like the fertigation and mist nozzles, could be arrived at using accepted procedures and standards. To develop the specifications of ETHE to be connected to greenhouse however it was necessary to carry out investigations to generate local data. Sharan and Jadhav ${ }^{17}$ monitored soil temperature regimes up to the depth of $3 \mathrm{~m}$ for one year in Ahmedabad and, based on that, developed expression for annual wave propagation into the soil,

$$
T(t, z)=26+10 e^{-\alpha z} \cos \left[\frac{2 \pi}{365}(t-105)-\alpha z\right] \ldots \ldots \ldots \ldots
$$

Where

$$
\begin{aligned}
& T \quad=\quad \text { temperature }\left({ }^{\circ} \mathrm{C}\right) \\
& t \quad=\quad \text { day of year beginning January } 1 \\
& z \quad=\quad \text { depth below surface }(\mathrm{m}) \\
& a=\sqrt{\frac{\omega}{2 k}} \quad=\quad \text { wave number } \\
& k \quad=\quad \text { thermal diffusivity of soil }\left(\mathrm{m}^{2} / \text { day }\right) \\
& =\quad \text { angular frequency of annual wave }(2 \pi / 365 \text { radians /day }) \text {. }
\end{aligned}
$$

Using diffusivity of local soil $\left(0.05469 \mathrm{~m}^{2} /\right.$ day $)$ in the equation, it can be seen that the amplitude of fluctuation will become negligible $\left(<1{ }^{\circ} \mathrm{C}\right)$ beyond $6 \mathrm{~m}$, with temperature becoming nearly constant, $26^{\circ} \mathrm{C}$. Embedding pipes so deep will involve high trenching costs. It was decided to put the pipe at $3 \mathrm{~m}$ depth where temperature would be expected to vary $3^{\circ} \mathrm{C}$ around mean over the months. A single pass ETHE was installed next at $3 \mathrm{~m}$ depth to determine the actual heating and cooling potential (Figure 1). 


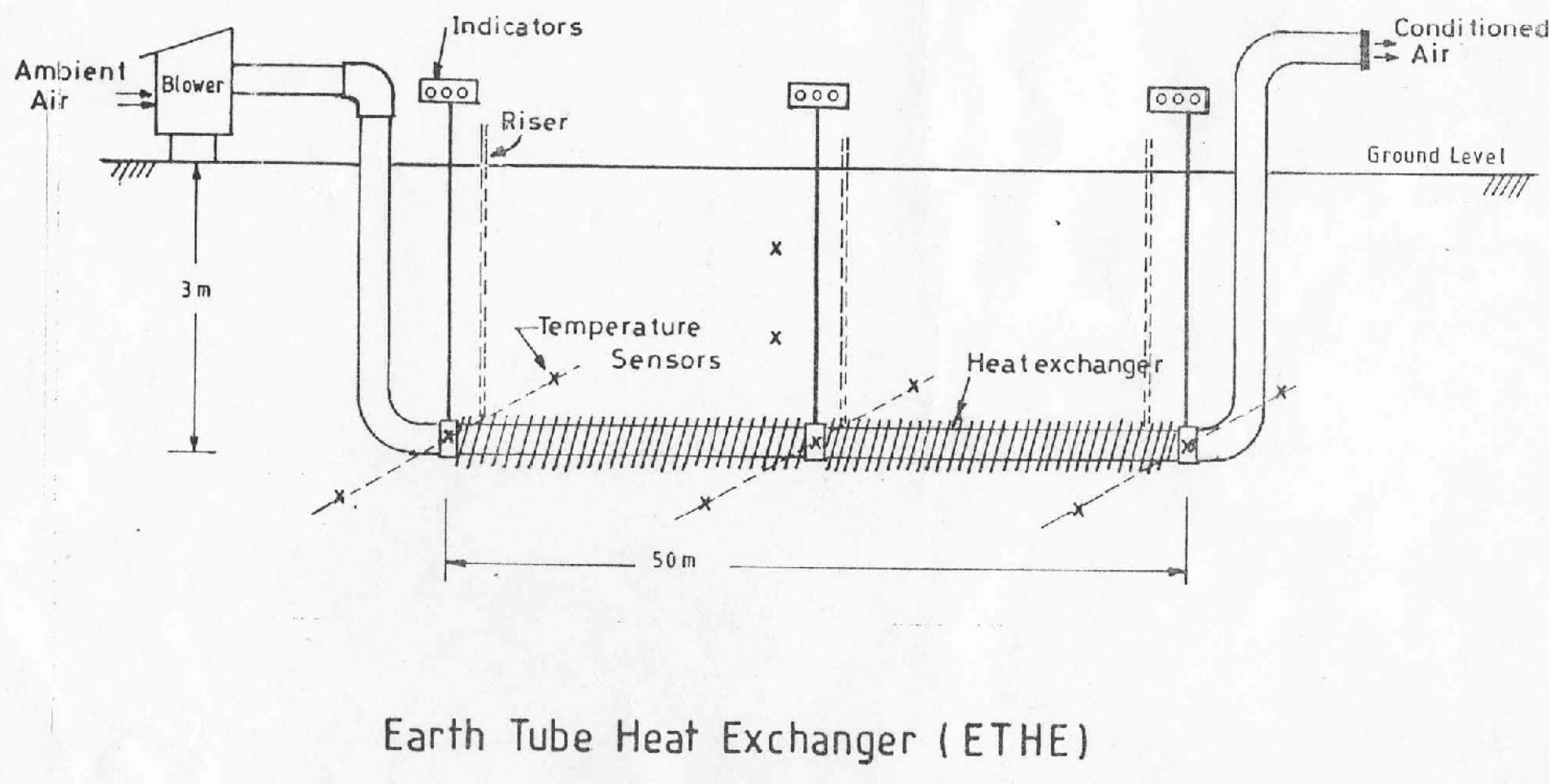

FIGURE 1 EXPERIMENTAL SINGLE PASS EARTH-TUBE -HEAT- EXCHAGER

Details can be seen in Sharan and Jadhav ${ }^{18}$. It was made of a $10 \mathrm{~cm}$ diameter $50 \mathrm{~m}$ long mild steel tube. Three sensors (thermister AD 590) were installed inside, at the inlet, at middle $(25 \mathrm{~m})$ and at outlet $(50 \mathrm{~m})$. A direct drive industrial type $0.38 \mathrm{~kW}$ fan was used, a blower with radial blades, with air velocity in the tube being $11 \mathrm{~m} / \mathrm{s}$, and a flow rate of $0.0863 \mathrm{~m}^{3} / \mathrm{s}$ or 5.17 $\mathrm{m}^{3} / \mathrm{min}$. ETHE was operated over three consecutive days each month for cooling tests and three nights of January for heating tests. When day tests were done, ETHE would be off during the nights - a break of 16-17 hours. It was observed from the sensor placed in soil near the entrance of the tube that the soil temperature regime was restored back to normal before start of new test. This is useful information as in the planned greenhouse facility it would be operated intermittently. Performance was broadly similar in cooling and heating modes. Tests in May showed that the ETHE cooled the ambient air by $10^{\circ} \mathrm{C}$. Heating tests of January nights showed that it heated the ambient air by $10.6^{\circ} \mathrm{C}$. Mean coefficient of performance (COP) in cooling and heating were 3.3 and 3.8 respectively. Most of the heat exchange, both in cooling and heating, occurred in the first $25 \mathrm{~m}$ length. Up to 12 hours of continuous operation did not show noticeable decline in performance.

Later, a mathematical model of the device was formulated ${ }^{19}$ for use as a flexible simulation tool to study effects of changes in air velocity, flow rate, pipe dimension etc. The problem modeled was - a thin walled pipe buried horizontally at a depth below surface, air at a 
known temperature is pumped into it from one end and exhausted into atmosphere from the other. The outer wall of the pipe is firmly in contact with the surrounding soil which is initially at a known temperature. Air exchanges heat with soil via the wall, heat is dispersed in the soil through conduction. The model was simplified and less comprehensive than that used by Puri ${ }^{11}$. Simplification was necessary since parameters related to thermo-physical properties (needed in Puri's model) were not readily available for soils of Kutch region at the time of planning. Main simplifications were as follows. The soil is treated as a homogenous medium with constant thermo-physical properties. The pipe diameter was assumed to be small compared to the depth at which it was buried; the air inside was assumed to be well mixed at uniform 'bulk' temperature; the flow regime in the pipe was fully developed. Axi-symmetric, time dependent Galerkin finite element method with triangular elements was used and simulations done in software PDE2D ${ }^{14}$.

Predictions from the model were checked by reproducing via simulation the results of cooling (May) and heating (January nights) and comparing with the measurements. In cooling mode simulation, temperature of air entering tube was maintained at $37^{\circ} \mathrm{C}$ which was the mean temperature of air during the seven hour test in the month of May. Soil temperature was set to $26.6^{\circ} \mathrm{C}$ as it was at the site then. After four hours, the model predicted temperature by the middle of the tube was $31^{\circ} \mathrm{C}$ and measured $30^{\circ} \mathrm{C}$; predicted outlet temperature was $28^{\circ} \mathrm{C}$, measured $27^{\circ} \mathrm{C}$. By eight hours, predicted temperature at mid-point was $31.5^{\circ} \mathrm{C}$ and at outlet $28.7^{\circ} \mathrm{C}$. Since the test was terminated after seven hours, measured values for eight hours were not available. But these are likely to be close to those at seven hours. Measured tube air temperature by mid-point (after 7 hours) was $30.5^{\circ} \mathrm{C}$ and at outlet still $27^{\circ} \mathrm{C}$. The comparisons suggested that the model yielded reasonably accurate predictions, for up to twelve hours of operation. 


\section{Hours}

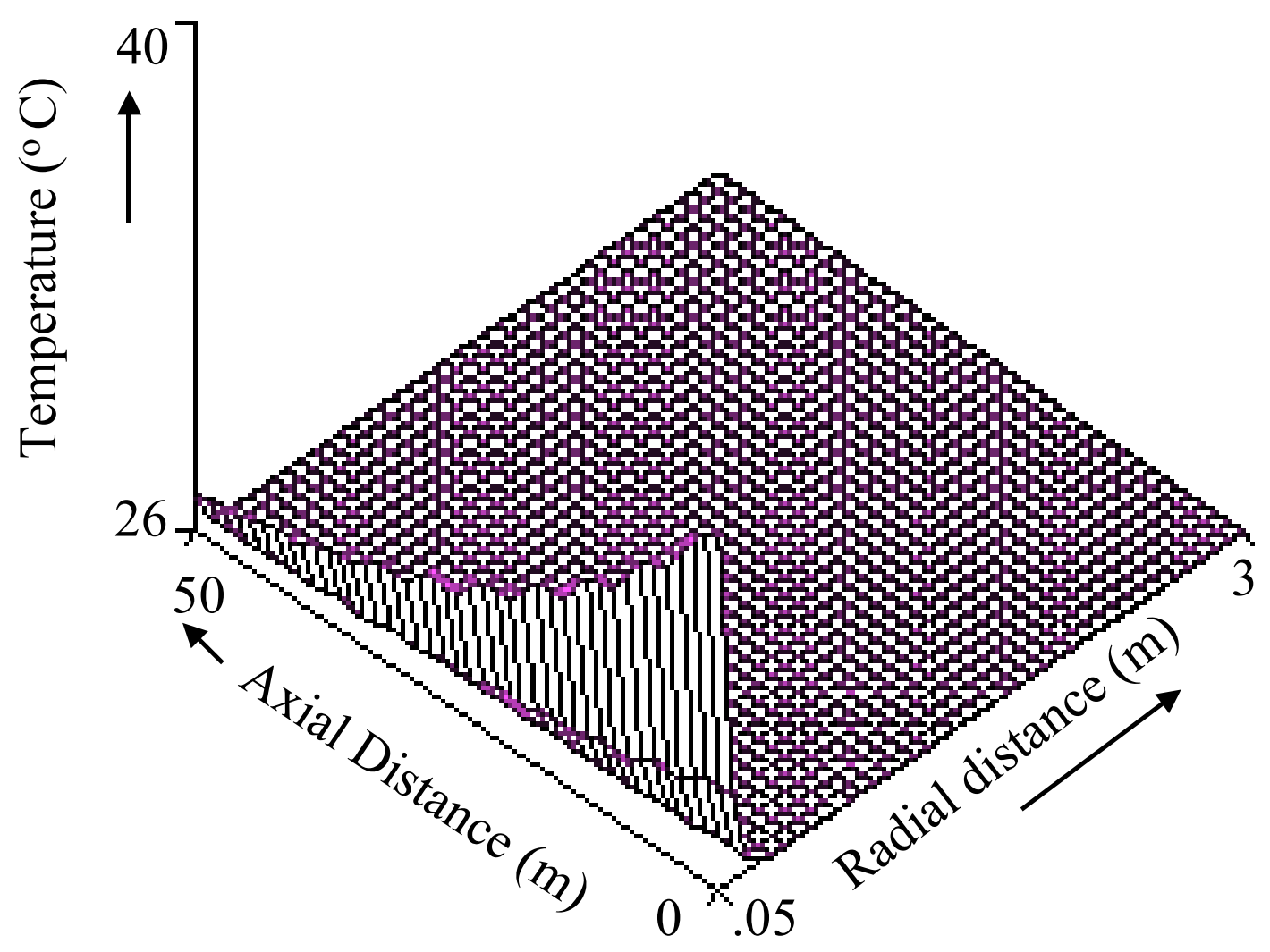

FIGURE 2 MESH PLOT OF SOIL TEMPERATURE AFTER 4 HOURS
$\left(\mathrm{T}^{*}=40^{\circ} \mathrm{C}\right.$
$\mathrm{T}_{0}=26^{\circ} \mathrm{C}$
$\mathrm{m}_{\mathrm{a}}=0.0887 \mathrm{~kg} / \mathrm{s}$
$\mathrm{v}=10 \mathrm{~m} / \mathrm{s}$ ) 


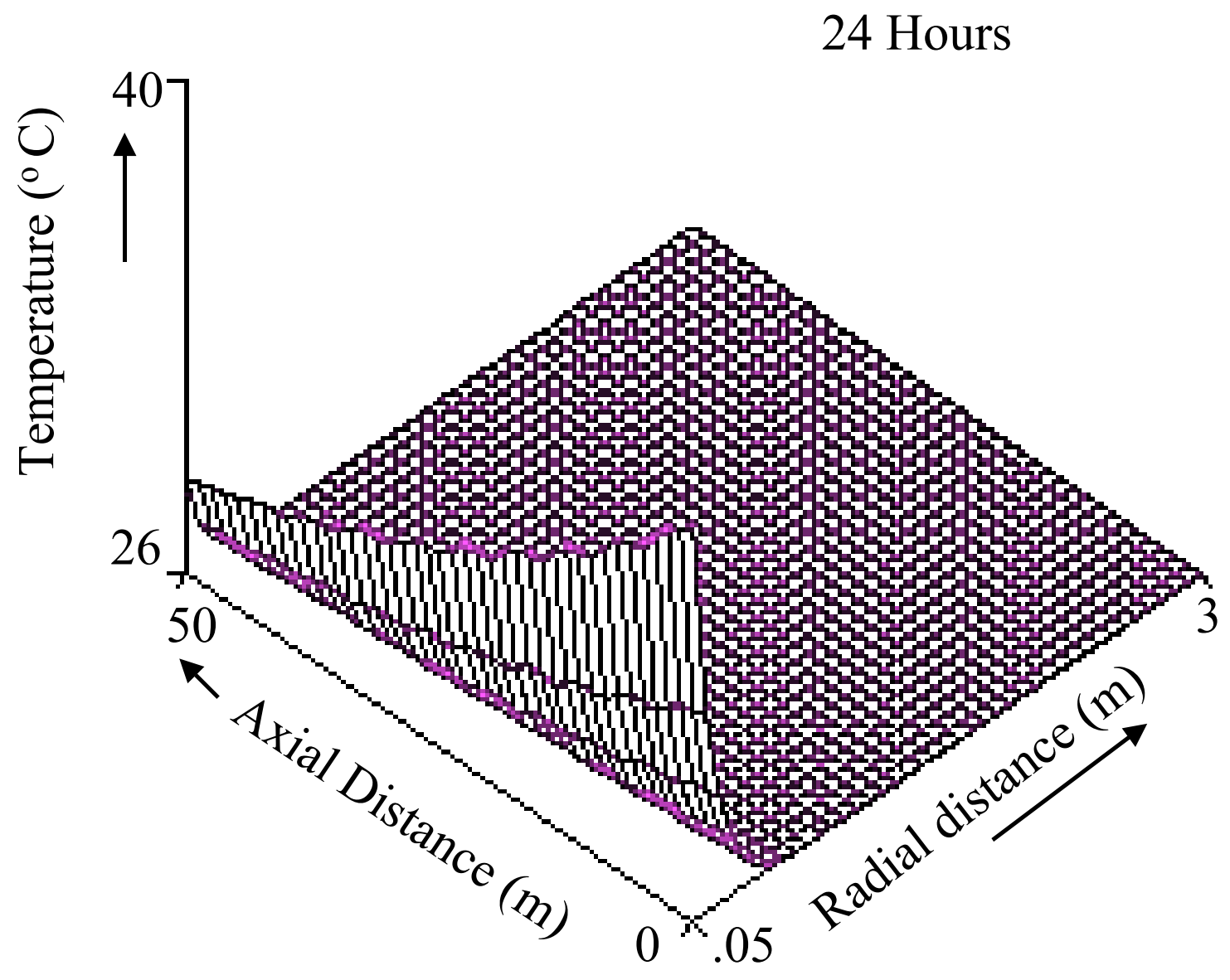

FIGURE 3 MESH PLOT OF SOIL TEMPERATURE AFTER 24 HOURS

$$
\left(\mathrm{T}^{*}=40^{\circ} \mathrm{C} \quad \mathrm{T}_{0}=26^{\circ} \mathrm{C} \quad \mathrm{m}_{\mathrm{a}}=0.0887 \mathrm{~kg} / \mathrm{s} \quad \mathrm{v}=10 \mathrm{~m} / \mathrm{s}\right)
$$

Simulations were carried out to examine the heating of soil around the pipe as the ETHE operated. This was needed to determine the distance that must be maintained between pipes if several of these have to be laid in parallel for large flow rate. Figure 2 and Figure 3 taken from, Sharan and Madhvan ${ }^{18}$, show mesh plots of soil temperature. After four hours the temperature at the entrance of the pipe rose from $26^{\circ} \mathrm{C}$ to $35.8^{\circ} \mathrm{C}$. The heating effect was seen up to a radial distance of $27 \mathrm{~cm}$ (2.7 times the pipe diameter). The heated annulus tapers along the pipe downstream. At the outlet $(50 \mathrm{~m})$ after 4 hours the soil annulus affected by rise in temperature is only $12 \mathrm{~cm}$ radius (one pipe diameter). By the end of 24 hours, the heated annulus at the entrance extends to 5.7 diameters, at outlet 4.2 diameter. It was inferred that pipes would need to be $>6$ diameter apart to avoid thermal overlap in prolonged operation. 

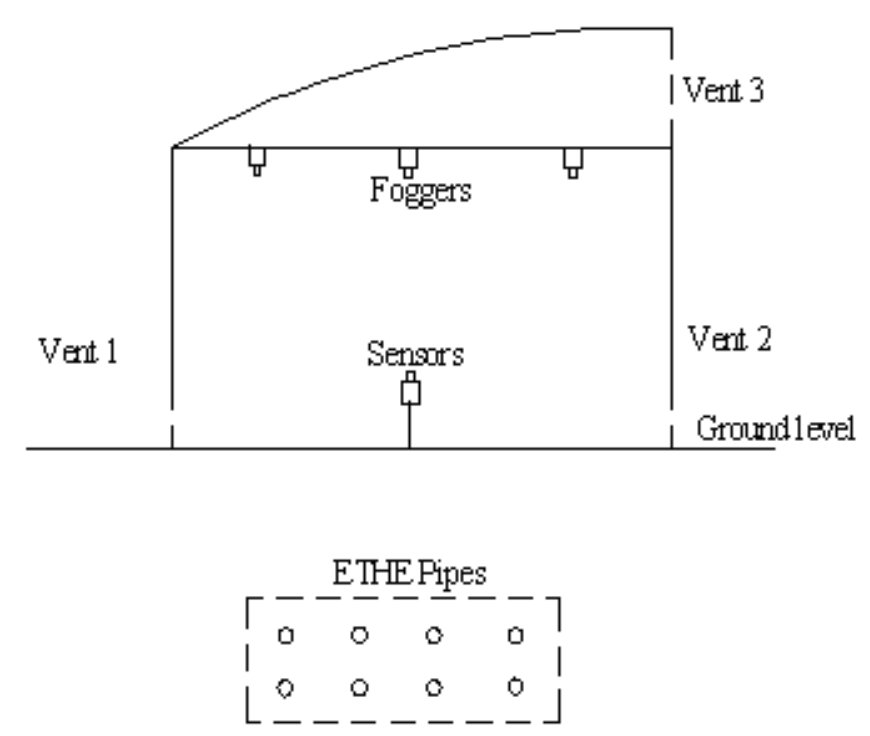

\section{FIGURE 4 SCHEMATIC DIA GRAM OF GREENHOUSE}

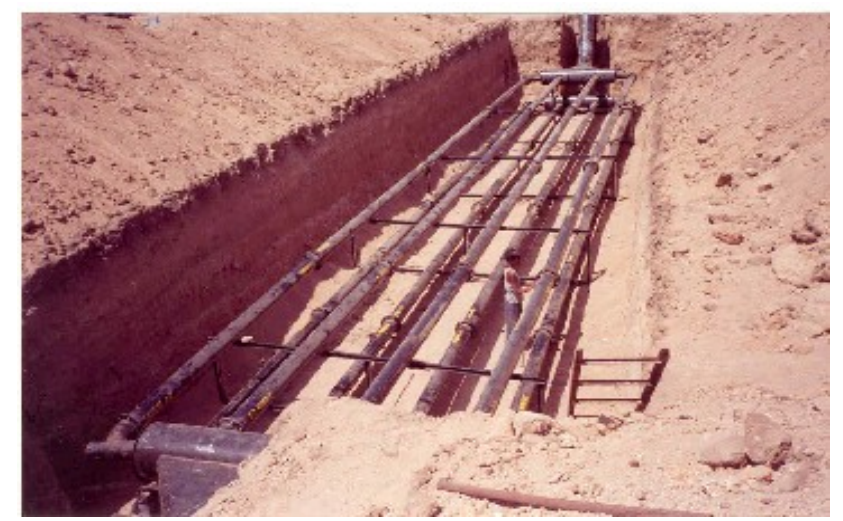

\section{FIGURE 5 EARTH TUBE HEAT EXCHANGER BEFORE BACKFILL}

\section{Greenhouse facility at Kothara}

Using the above results, a new facility was constructed at Kothara consisting of a greenhouse and a large ETHE connected in closed-loop. There was also provision for natural ventilation and supplementary mist nozzles, besides the usual fertigation and other internal units. The greenhouse was a single span, saw-tooth structure $(20 \mathrm{~m} \mathrm{X} 6 \mathrm{~m} \mathrm{X} 3.5 \mathrm{~m})$ with floor area of $120 \mathrm{~m}^{2}$ and volume $360 \mathrm{~m}^{3}$. It is clad with 200 micron UV stabilized clear single skin PE film with transmittance of 0.8 (manufacturer's data). There are three closable vents, each $20 \mathrm{~m} \times 0.5$ $\mathrm{m}$, two at the base of the side walls, a third at the top of higher side (Figure 4). Vents are screened with commercially available stainless steel wire mesh - 15 strands per inch in each direction and whole size less than a $1 \mathrm{~mm}$. Unscreened vent area was $25 \%$ of the floor area. A retractable shade net was put on top. Shade net was installed just above the cladding. Net used was green-black with shading of 50\% (manufacturer data). There are 39 mist nozzles (manufacturers data operating pressure $4 \mathrm{~kg} / \mathrm{cm}^{2}$, discharge $0.007 \mathrm{~m}^{3} / \mathrm{hr}$ ) installed $3 \mathrm{~m}$ 
overhead on a grid pattern. The ETHE connected to the greenhouse provides air flow rate equivalent to 40 changes per hour. It is made of eight pipes that connect to identical headers on both ends (Figure 5). Pipes are of mild steel with wall thickness of $3 \mathrm{~mm}$, arranged in two tiers. The first tier is at $3 \mathrm{~m}$ and the second is at $2 \mathrm{~m}$ depth. Pipes are $23 \mathrm{~m}$ long and $20 \mathrm{~cm}$ diameter, placed $1.5 \mathrm{~m}$ apart laterally. Inside air from greenhouse is drawn, cycled through buried pipes and returned to the house. A centrifugal blower powered by $4 \mathrm{~kW}, 1440 \mathrm{rpm}$ motor moves the air.

An eight-channel data logger (from Weather Technologies India) was used to record ambient temperature, global solar radiation, relative humidity, wind speed (three-cup anemometer) outside; and air temperatures at three locations, relative humidity at one location inside greenhouse. The outside sensors of temperature and humidity are placed two meters away from the greenhouse boundary and one meter above ground. The anemometer and the radiation sensor are located over a roof of a building $5 \mathrm{~m}$ high building $20 \mathrm{~m}$ away from the greenhouse. There are four sensors inside, three for temperature and one for humidity. All four are placed along the centre line one meter above the ground and weather shielded. One temperature sensor is placed at west end, one in the middle and one at the east end of the house. The humidity sensor is placed at the middle too. Data logger has LCD display, real time clock calendar, and serial output port for connecting it to PC with parallel interface to printer or memory module.

\section{RESULTS AND DISCUSSION}

Cropping in greenhouse facility

Greenhouse has been under investigation for several years. Usually two crops can be raised from July to April. It is closed in most of May and June. Initially cropping was done through these months as well, but it becomes too hot, leading to poor quality undersize fruits. Several vegetables have been grown - tomato, okra, chilly, capsicum (bell pepper). Tomato has been grown over three rounds. Previous results were reported in Sharan at al. ${ }^{20}$, Sharan and Jethva ${ }^{22}$. Here results of yet another round of tomatoes raised in the season of 2007-08 are discussed. Cropping practices were same as before except one change. Mist nozzles were not operated. This was because in previous rounds owing to poor water quality, mist caused deposits on the leaf surface leading to injury. Commercial hybrid (US 1080) was planted (45 X $45 \mathrm{~cm}$ ) on 15 November, 2007. Fruit became ready for first picking 103 days after planting. The crop lasted more than 6 months through parts of June. Plants, pruned and trailed, grew to height of up to $1.6 \mathrm{~m}$. Fertilizers were applied in liquid form via the drip line as per the stipulations of seed suppliers. Watering was done through drip, with duration and frequency decided by observation. Water quantity applied was noted using mean calibrated discharge of emitters and duration. Fruit size, shape and weight were normal to the type. Yield was $68 \mathrm{t} / \mathrm{ha}$. The total water applied was $266 \mathrm{~mm}$ for irrigation and none for misting. Water used in open-field in this area would be twice as much and crop yield would be less than half. 


\section{Effectiveness of control measures}

Control measures available are:

a) Natural ventilation + shade net - typically used in combination, although some days in winter may not need shade; usually vents opened at 10:00 and closed at 17:00.

b) Shade net + forced ventilation from ETHE - employed when heating is needed as on winter nights of December, January, usually turned on at 22:00 and off 06:00; it is also for cooling during day if greenhouse has tall and dense foliage which hindered natural ventilation.

c) Shade net + ETHE + mist spray - usually needed in hotter months March, April onwards; as stated in this round it was not deployed.

Figure 6 shows the temperature on November 15 with measure (a) in place. The peak inside temperature was $35^{\circ} \mathrm{C}$ (mean of three locations), which was nearly equal to the peak ambient outside. The inside was marginally cooler than outside in the first half and warmer similarly in the afternoon. This appears to be the expected phase difference. Computations had indicated that measure (a) would reduce peak, $\Delta \mathrm{T}$, to only about $3{ }^{\circ} \mathrm{C}$ at mid-day in November (Table 1). It is plausible that some extra cooling was afforded by evaporation from largely bare and wet soil surface. Soon after planting for many days, the watering was done manually on the surface around seedlings. Mean inside humidity during the day was $62 \%$. Minimum and maximum temperature range computed for November is $15-33{ }^{\circ} \mathrm{C}$ ( column 6 Table 1 ), in comparison to the range actually observed during the entire month $\left(14-35^{\circ} \mathrm{C}\right)$. Figure 7 shows the temperatures inside and outside on December 14-15 with night heating on. ETHE was turned on at 22:00 hours and turned off at 06:00 hours next morning. It kept the inside temperature above $13 \mathrm{C}$. Day time peak temperature on 15 th was $27 \mathrm{C}$. Expected range of temperatures inside as per earlier computations for December was $7-28{ }^{\circ} \mathrm{C}$, and actual range in the first half (before night heating started) was $11-32{ }^{\circ} \mathrm{C}$. Heating was required at night from mid December to mid - January. Figure 8 shows the temperatures on January 14-15 with night heating, which was thereafter discontinued. Expected range of temperatures inside as per earlier computations for January was $8-34{ }^{\circ} \mathrm{C}$, actual observed maximum was $32^{\circ} \mathrm{C}$.

Ambient temperatures begin to rise after January. Expected range of temperatures inside as per earlier computations for February was $9-35^{\circ} \mathrm{C}$; actual observed range was not available due to download malfunction in data logger. Figure 9 shows the temperature on March 15. Maximum temperature did not exceed $34{ }^{\circ} \mathrm{C}$ inside greenhouse and humidity was an average of $63 \%$. Inside was marginally cooler, most likely due to evaporation - transpiration cooling. By this time the crop was over $1.5 \mathrm{~m}$ tall with dense foliage. The mean humidity level also was higher compared to outside (53\%). Expected range of temperatures inside as per earlier computations for March was $17-39{ }^{\circ} \mathrm{C}$, observed $14-36{ }^{\circ} \mathrm{C}$.

Figure 10 shows the temperatures on April 15. By this time the tall and dense foliage trailed to structure above appeared to hinder natural ventilation. Accordingly, measure (b); shade net and forced ventilation via ETHE was used during the day. Vents were kept closed. Maximum temperature inside reached a peak of $34{ }^{\circ} \mathrm{C}$, nearly same as the ambient. Mean humidity inside was $64 \%$, compared to $49 \%$ outside. Expected range of temperatures inside as per earlier computations for April was $20-39{ }^{\circ} \mathrm{C}$, observed was $15-37{ }^{\circ} \mathrm{C}$. Figure 11 shows the temperatures on May 15. The greenhouse inside reached a peak of $36^{\circ} \mathrm{C}, 3{ }^{\circ} \mathrm{C}$ higher than that of the ambient. Same measure of control (b) was in place. The average humidity inside was $70 \%$ and $63 \%$ outside. 


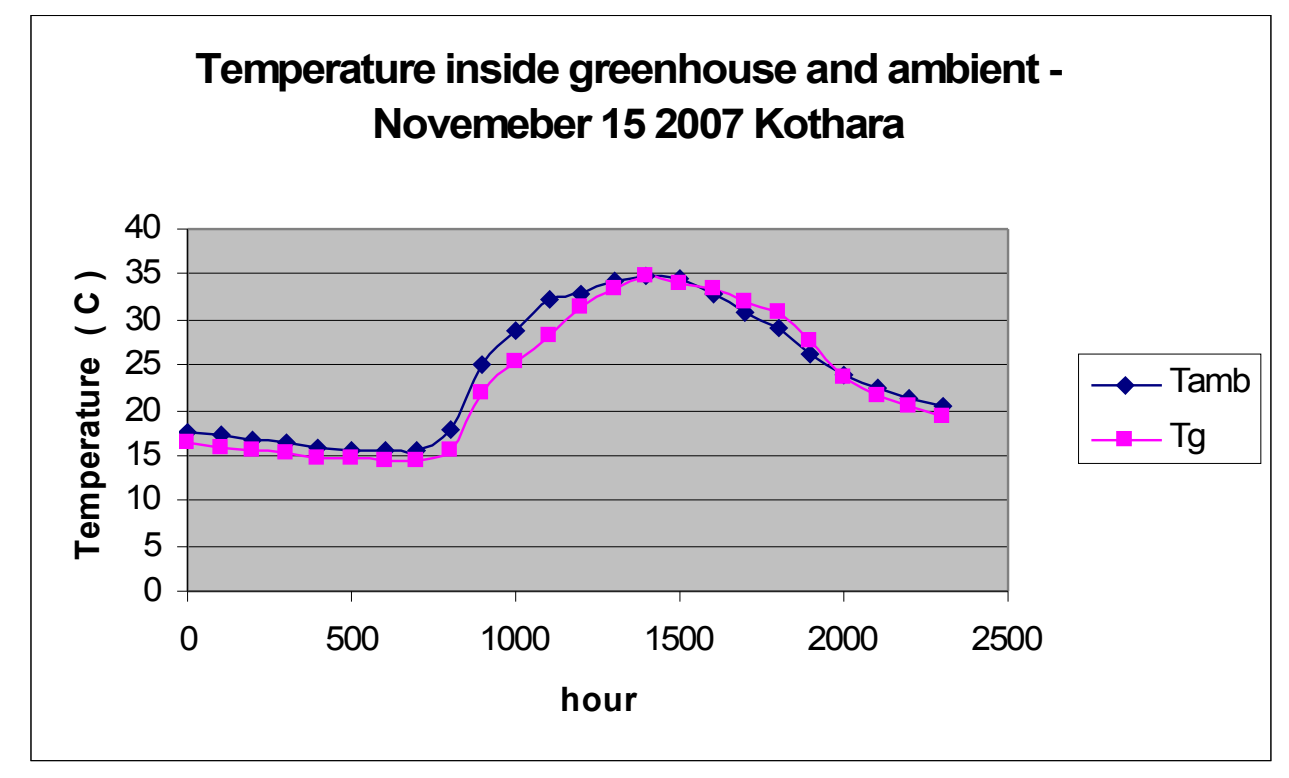

FIGURE 6 TEMPERATURES INSIDE GREEN HOUSE AND AMBIENT

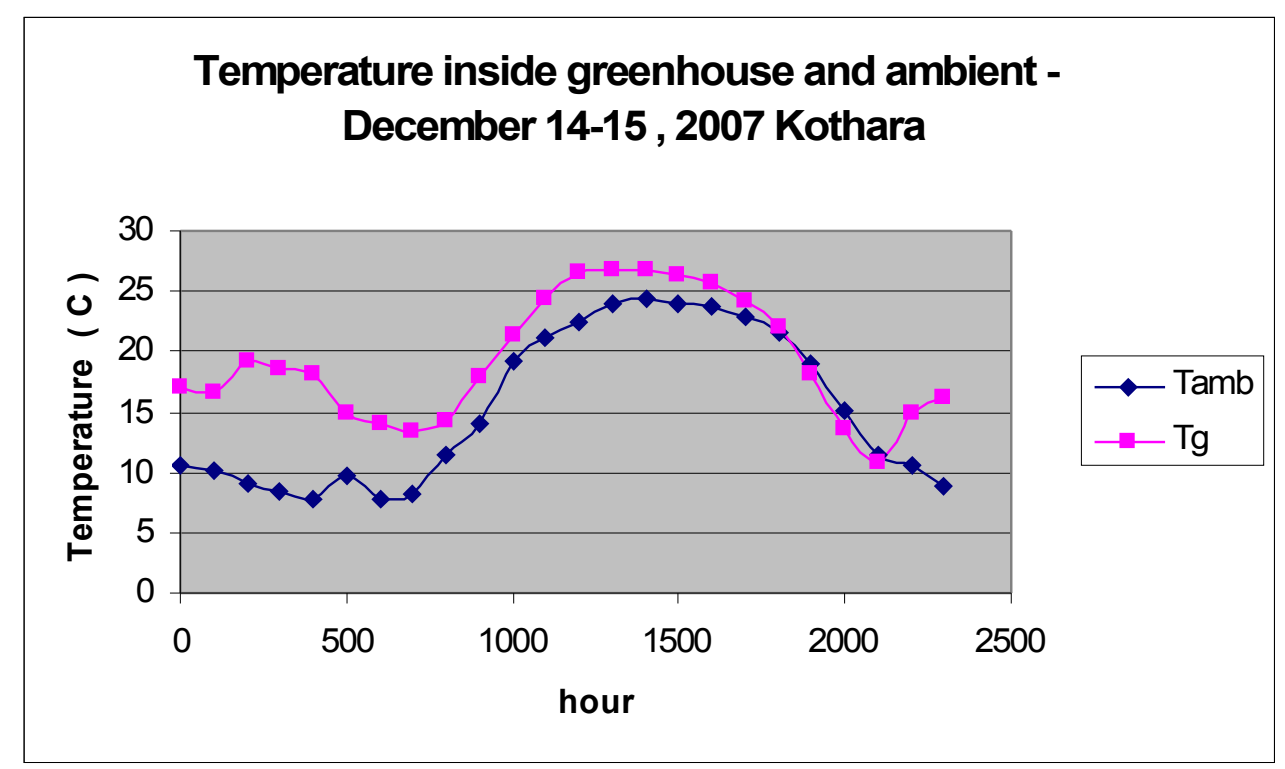

FIGURE 7 TEMPERATURES INSIDE GREEN HOUSE AND AMBIENT NIGHT HEATING 


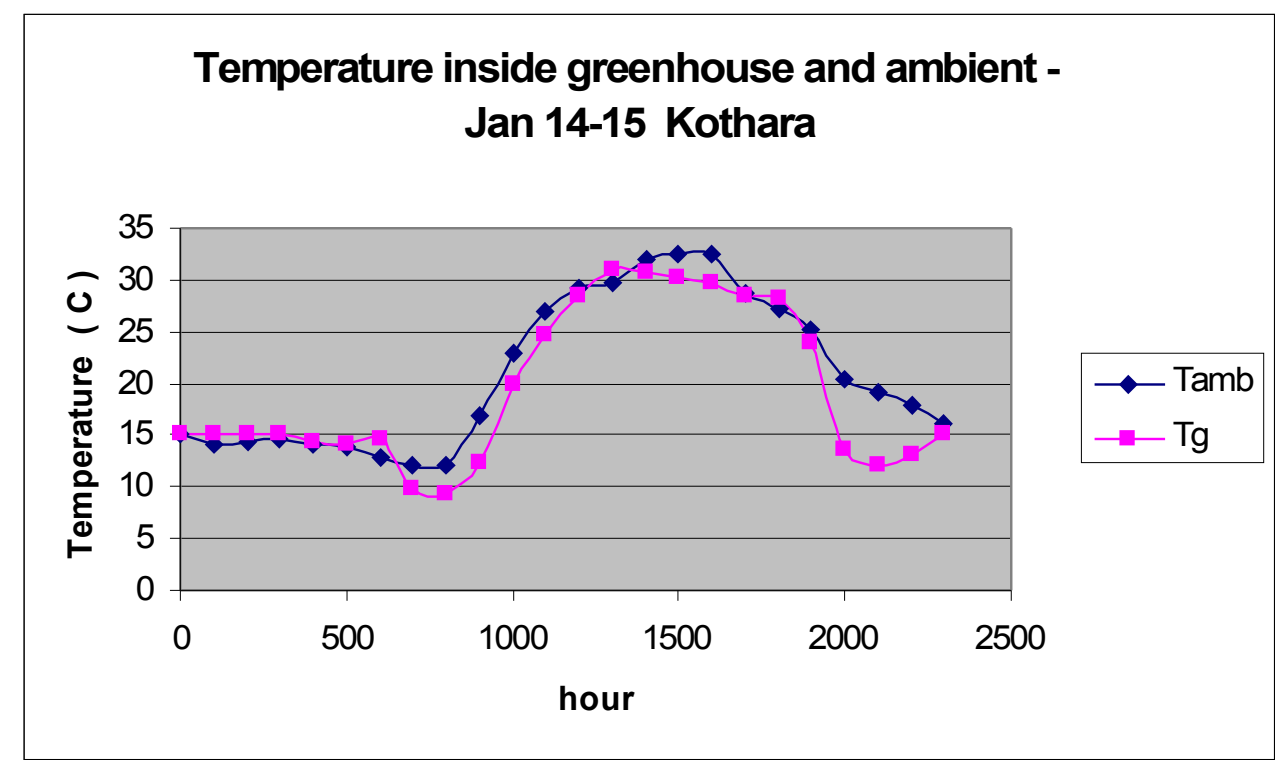

FIGURE 8 TEMPERATURES INSIDE GREEN HOUSE AND AMBIENT NIGHT HEATING

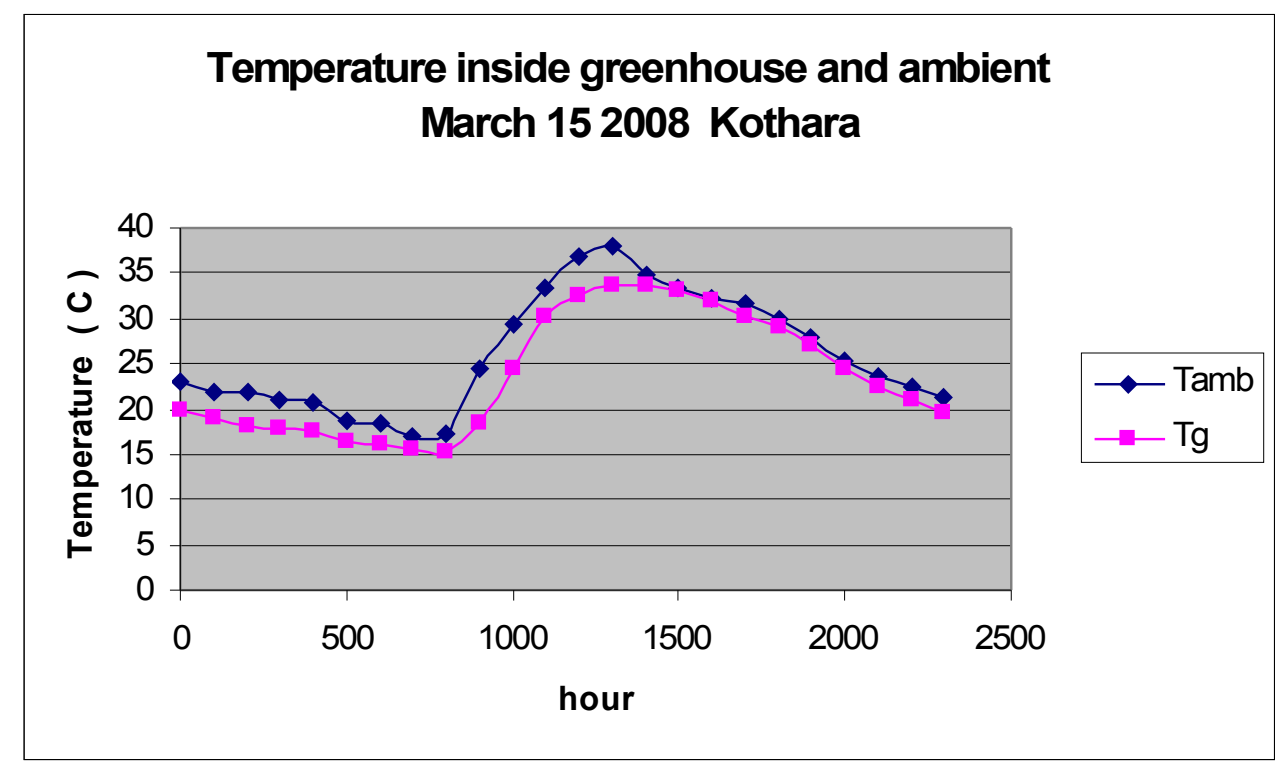

FIGURE 9 TEMPERATURES INSIDE GREEN HOUSE AND AMBIENT 


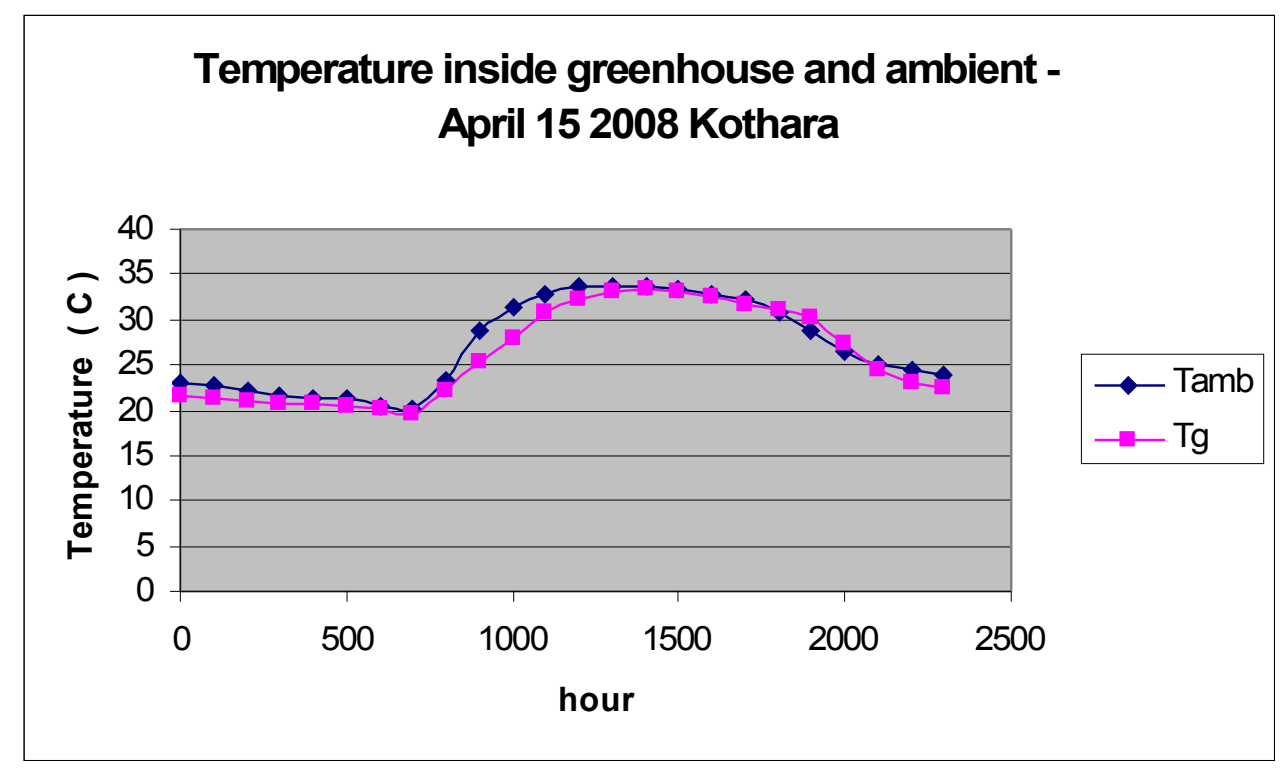

FIGURE 10 TEMPERATURES INSIDE GREEN HOUSE AND AMBIENT

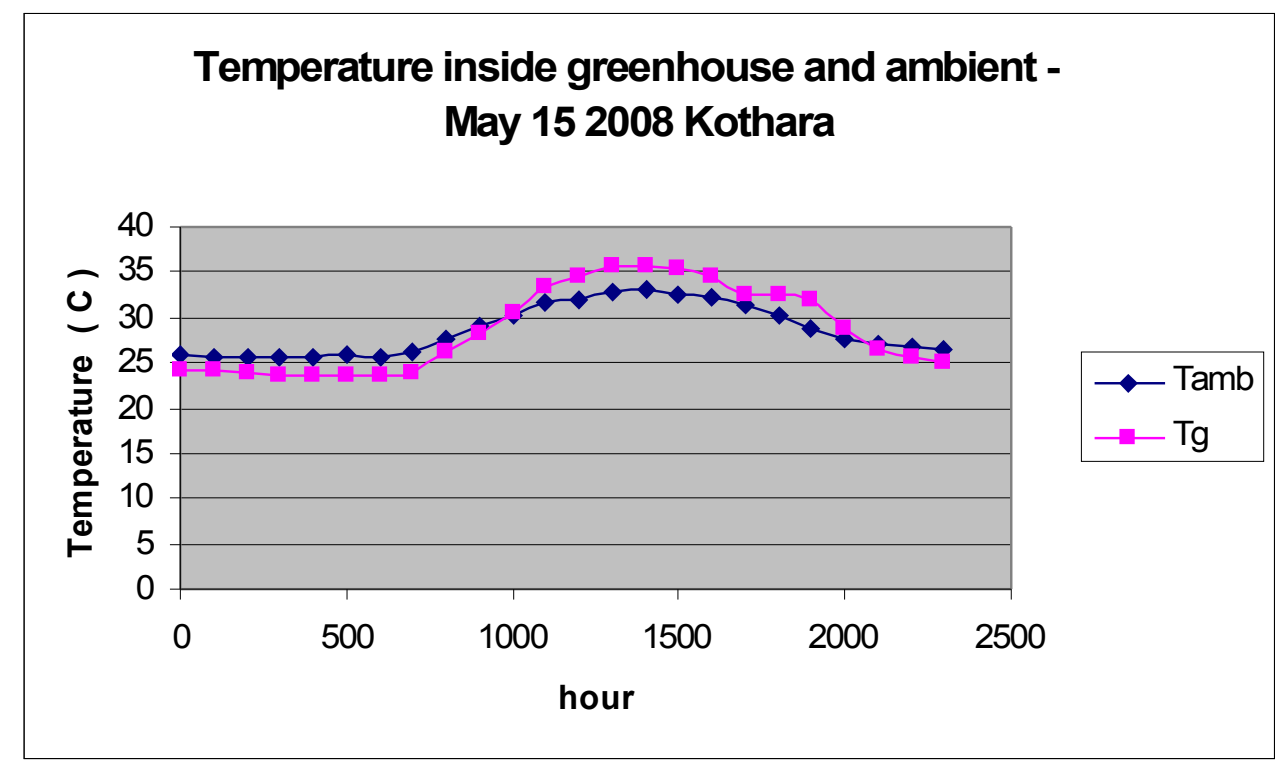

\section{FIGURE 11 TEMPERATURES INSIDE GREEN HOUSE AND AMBIENT}

The expected range of temperatures inside as per earlier computations for May was $21-38{ }^{\circ} \mathrm{C}$, observed was $20-38{ }^{\circ} \mathrm{C}$. Figure 12 shows the temperatures on June 8 with same measure of control. The peak inside temperature was $38^{\circ} \mathrm{C}$, outside $37^{\circ} \mathrm{C}$. Mean humidity inside was $74 \%$, outside was $64 \%$. Expected range of temperatures inside as per earlier computations for June was $20-37{ }^{\circ} \mathrm{C}$, observed was $22-37^{\circ} \mathrm{C}$. Fruit size in June became smaller, crop was 
cleared soon after. To recapitulate, the top shade and natural ventilation in cooler months, top shade and forced ventilation with ETHE kept the inside temperature close to that outside. But as radiation levels and ambient temperatures rise in May and June, inside temperature did exceed by $1-3{ }^{\circ} \mathrm{C}$. The humidity levels were generally lower than required for tomatoes, especially in cooler months (December, January). Since mist nozzles were not operated it could not be improved. For future, it is planned to change nozzle location to the end from which ETHE air enters the greenhouse. This is to prevent depositions on plants while humidifying the incoming air.

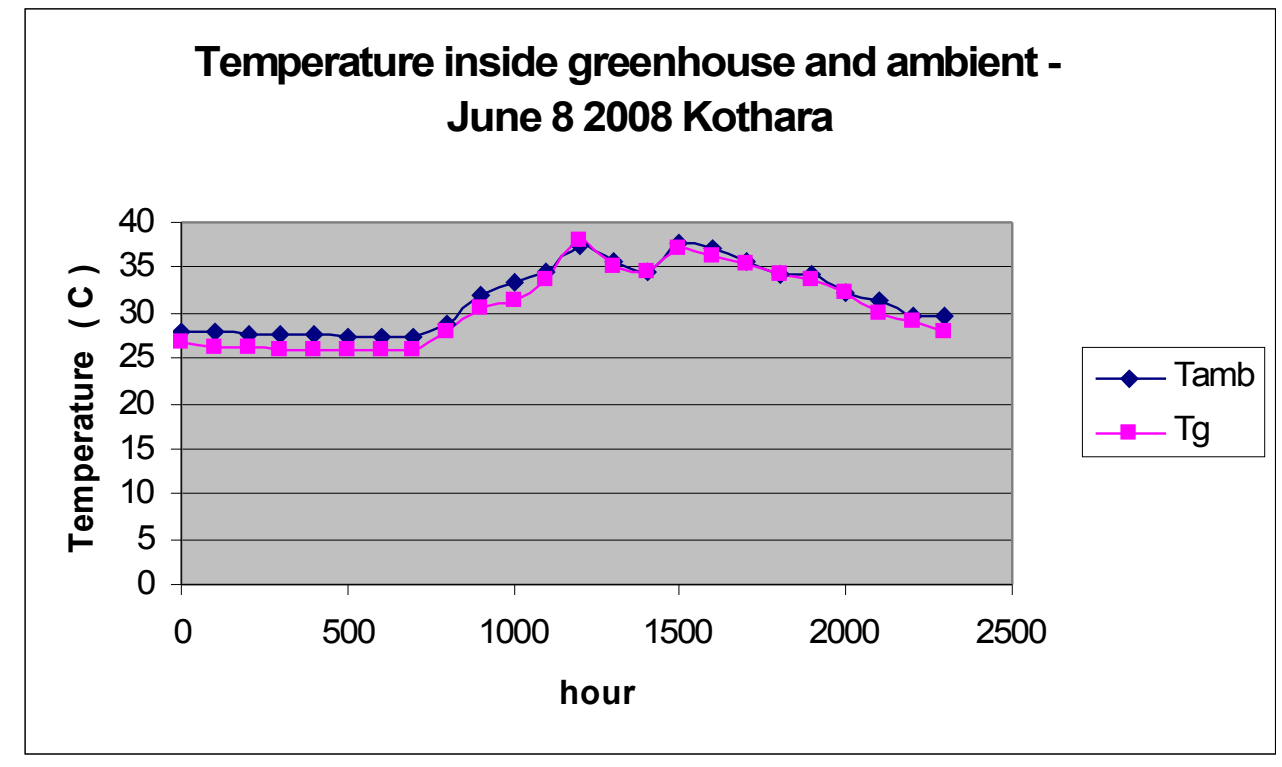

FIGURE 12 TEMPERATURES INSIDE GREEN HOUSE AND AMBIENT

\section{LEARNING AND PARTNERSHIPS}

The sequential presentation above may give the impression of a pre-planned research project. In reality the work sequence evolved driven by the results achieved and insights gained. The engagement that has now spanned several years began by a visit to the region to observe and understand the problems when a severe drought occurred in Kutch region causing widespread shortage of food, fodder and water; and leading in turn to large scale cattle fatalities and displacement of people. The author traveled to rural parts expressly to identify problems to work on. Direct observation and conversation with people led to conceptualization of possible solutions. A concept paper was drafted arguing that open-field cropping will always be a low yielding, risk-prone business under the prevailing climatic and agronomic conditions. Covered cultivation could be a better way to use scarce water, grow high value produce on a steady basis. But at the time there was no experience in the country on greenhouse cropping in hot arid regions. A symposium was therefore convened to discuss the feasibility of this approach. Participating engineers and other scientists pointed out that unless cooling was possible without the use of water, greenhouse cultivation would not be an advantage. This led to researches on 
ETHE, starting from measurement of deep soil temperature. Only after the results showed the possibility of using deep strata of soil as sink and source, an outline of future work emerged.

As the outline began to be clear, it was necessary to define the goal of the endeavor. Goal was set as - a practical solution - development of greenhouse especially suited to the environment of the region and one which would help farming community to improve incomes. In remote rural areas of this region, many basic problems have remained unsolved because research endeavors usually ended up contributing to knowledge (publications), but not products or solutions that people could use. An emphasis on - solution or product - is important.

It became necessary to set-up an experimental station in the rural part of the region. At that stage however there was no funding, and no physical facilities to work. Cummins Foundation (India) was approached to help with funds and Gujarat Energy Development Agency (GEDA) with infrastructure. Former supported innovative application of engineering to solve problems in rural areas and therefore responded positively by providing funding to rent accommodation and for small office staff. Latter provided us access to their small campus in the village of Kothara. GEDA also funded our initial researches in ETHE. These two partnerships were crucial in getting started. Partnership with GEDA continues. Development of solutions entails greater uncertainties than is usually the case with well (and narrowly defined) research projects. It is important to find partners who appreciate this. Sharing the results of the work, progress and set-backs with the partners frequently is helpful in retaining them and also in finding others. Regular reports and when possible visits to the site by the partners are a good practice in such endeavors.

Development and Outreach Station ( DOS ), Kothara hosts up to six engineering summer interns each year who work with ETHE, greenhouse and other projects. A total of 35 interns have worked there over the years. Requests from graduate students have also come from overseas (Spain, Mexico, Kuwait, Brazil ) seeking clarifications via emails on ETHE research for their own areas.

\section{BENEFITS TO THE REGION}

Benefits to the region accrued as the new technology was introduced. The first commission to build a air-conditioning system using ETHE came from the Ahmedabad zoological garden which wanted it for the dwelling of tigers ${ }^{16}$. The zoo authorities saw the cooling and heating mode results and noted that ETHE could be appropriate for animals especially as it did not add humidity to dwelling which is unhealthy for the animal that lack sweat glands. The installation pioneered the use of such device in a zoo. It is regularly used as training and demonstration unit for other zoo keepers who come for refresher courses periodically. Subsequently two similar systems were made for milk cows at animal science departments of two agricultural universities, Anand and Junagadh. These units are also useful for teaching environmental management in cattle houses. Requests continue to be received from dairy cattle owners for such installations. Enquiries also come for adaptation of ETHE for human residences and work places. Given our focus on agriculture and livestock, we responded only in a limited manner. One large auditorium at the Science City, Gandhinagar and one small residence of an architect were built to improve comfort. Two local entrepreneurs have been trained in fabrication, installation and maintenance of ETHE systems. 
As cropping in the greenhouse at Kothara began to be done and findings were disseminated among the farming community in the district via twice -a- year 'open house' events. Vegetables from greenhouse were sold in the village bazaar which too helped people to know the project outcomes. One greenhouse was built on commission from a local NGO who intended to use it for women's training. Visit by interested farmers to our facility has increased and enquiries are received from distant areas. Three commercial vegetable growing greenhouse facilities (at Delhi, Chandigarh and Hyderabad) were provided consulting advice to install ETHE. A new set-up Sustech Centre has been created to promote and market the arid area greenhouse technology in the region and train farmers in its operation.

ETHE has proved effective in heating mode and to a significant extent also in cooling. Beginning 2008, the problem of desalination of brackish groundwater was included in the research program. Lack of cost-effective technology to produce agriculture quality water for use in greenhouse is the next challenge. For this part we first partnered with one firm in the U.K. who have installed greenhouses in three locations in arid coasts and which produce fresh water as byproduct of cooling? The work could not be carried out as the firm did not receive funding support it was anticipating. Another agency was then approached who have installed large sea water desalination plants in a remote island on Indian ocean of Low Temperature Thermal Desalination ( LTTD ) type. These use temperature differential of sea water at surface and at large depth to vaporize and then condense water. We had proposed the LTTD process be made possible inlands (as against sea shore) by using solar energy to create temperature differential comparable to that at the sea. Initially the LTTD engineers felt it could be done. Subsequently they withdrew. The challenge still remains to be met.

\section{CONCLUSION}

Extensive visits to the region and conversation with people is a useful way to identify problems to work on. It is especially necessary in rural parts of this region where connect between the lay people and the R\&D institutions is not strong. R\&D institutions often work on problems that do not include the ones that people consider important and urgent. Also it is important to set the goal of work as - solution - and not just a contribution to knowledge as is commonly the case. Development of solution does entail greater challenges and uncertainties which need to be recognized. Partnerships need to be created to improve the chances of success.

The experience has shown that while greenhouse technology has the potential to improve productivity and livelihoods in hot semi-arid regions in the north-west India, environmental control is a continuing challenge. An experimental greenhouse - coupled to a 40 air changes per hour earth-tube-heat-exchanger and additional provision of 50\% shading, natural ventilation of $25 \%$ floor area and mist nozzles for occasional use - has been under investigation. Use of these provisions in sequence and in conjunction makes cropping possible over a ten month span, from July to April.

Commercial hybrid tomato (US 1080) was grown in the season of November to June. Unlike earlier rounds mist was not employed. Environmental control was done with natural ventilation and shade net in cooler periods, forced ventilation with ETHE and shade net in warmer periods. In the cold nights of December and January, heating was done using ETHE with top shaded. Heating was very effectively achieved with ETHE keeping the inside temperatures well above $12^{\circ} \mathrm{C}$, when without its deployment inside temperatures would go down to $8-9^{\circ} \mathrm{C}$. Natural ventilation and shade kept the day time inside temperature below $34^{\circ} \mathrm{C}$ till 
March. In subsequent months, ETHE was deployed and vents closed. When the crops became tall and dense, forced ventilation was more effective. This measure kept the inside temperature nearly equal to outside, except in May and June when it was $2-3{ }^{\circ} \mathrm{C}$ higher. Fruit size, shape and weight were normal to the type until early June. Yield was $68 \mathrm{t} / \mathrm{ha}$. Total water applied was $266 \mathrm{~mm}$ for irrigation (none for misting). Water used in open-field in this area would be twice as much and crop yield less than half. While not operating the mist nozzles did prevent leaf injuries and saved water, humidity levels could not be corrected when required. In future placement of the nozzles would need to be modified to permit humidity improvement without causing leaf depositions. The approach appears to be an effective and promising way to do greenhouse cropping in this region.

\section{ACKNOWLEDGEMENT}

We thank the World Bank for funding support, the Gujarat Energy Development Agency, for providing the ground for experimentation and the Indian Institute of Management for facilities. Engineers, Sanjay Kumar and M.P. Chandra provided research assistance.

\section{REFERENCES}

1. Al-Jamal, K. (1994) Green house Cooling in Hot Countries, Energy Vol. 19, No. 11 pp. 1187-1192.

2. Arabel, A. , Yakutieli, O., Barak, M. (1999) Performance of a fog System for Cooling Greenhouses , J. Agric. Engng Res. (1999) 72 , 129-136.

3. Arbel, A., Barak, M. Shklyar, A. (2003) Combination of Forced ventilation and Fogging System for Cooling Greenhouses, Biosystems Engineering ( 2003 ) 84 (1), $45-55$.

4. Baille, A., Kittas, C., Katsoulas, N. (2001) Influence of whitening on green house microclimate and crop energy partitioning, Agricultural and Forest Meteorology 107, 293-306.

5. Giacomelli, G.A., Ginger, M.S., Krass, A. E., Mears , D.R. (1985) Improved Methods of Greenhouse Evaporative Cooling, Acta Horticulturae 174, 1985.

6. Kittas, C. (1995). A simple climagraph for characterizing regional suitability for greenhouse cropping in Greece. Agricultural and Forest Meteorology, 78: 133-141.

7. Kittas, C., Boulard, T., Mermier, M. and Papadakis, G. (1996). Wind Induced Air Exchange Rates in a Greenhouse tunnel with Continuous Side Openings. Journal of Agriculture Engineering Research, 65: 37-49.

8. Kittas, C., Baille, A., Giaglaras, P. (1999) Influence of Covering Materials and Shading on the Spectral Distribution of Light in Green house, J. Agric. Engg Res. 73, 341-351.

9. Mears, D. (1990). Opportunities for collaborative Indo/US greenhouse research. In The Use of Plastics in Agriculture. New Delhi, Oxford IBH.

10. Nelson , Paul V. (1997) Greenhouse Operation and Management, Prentice Hall 1997 , ISBN-100133746879.

11. Puri V.M. (1986). Feasibility and performance curves for intermittent earth-tube heat exchangers. Trans ASAE, 29(2). March-April, pp.526-532. 
12. Santamouris M., Mihalakaha G. Balaras C.A. Argirioua Asimakopoulos D. and Vallinaras M. (1995). Use of Buried pipes for energy conservation in cooling of agricultural greenhouse. Solar Energy. Vol. 35, pp 111-124.

13. Sabeh , N.C., Giacomelli, G.A., Kubota,C. (2006) Water Use for Pad and Fan Evaporation Cooling of a Greenhouse in a Semi-Arid Climate, Proc. IS on Greenhouse Cooling, Ed. B.J. Bailey, Acta Hort. 719, ISHS 2006.

14. Sewell G. (2002). Finite differences, finite elements and PDEZD. Mathematics Department, University of Texas, El Passo.

15. Sharan G. (1997). Engineering the Agriculture in Extremely Arid Areas like Kutch. In: Agricultural Development Paradigm for the Ninth Plan Under New Economic Environment, by Bhupat M. Desai (Ed), Oxford \& IBH Publishing, New Delhi, pp 388-398.

16. Sharan G., Sahu R.K. and Jadhav R. (2001) "Earth Tube Heat Exchanger Based Airconditioning for Tiger Dwellings." Zoos' Print, 16:5, May 2001 (RNI 2:8)

17. Sharan G. And Jadhav R. (2002). Soil temperature regime at Ahmedabad. Journal of Agricultural Engineering, 39:1, January-March.

18. Sharan G., and Jadhav, R (2003). "Performance of Single Pass Earth Tube Heat Exchanger: An Experimental Study." Journal of Agricultural Engineering, 40:1, JanuaryMarch 2003, pp.1-8.

19. Sharan G. and Madhavan T. (2003). "Simulation of Performance of Earth Tube Heat Exchanger using a Mathematical Model." Journal of Agricultural Engineering, 40:3, July-September 2003, pp.8-15.

20. Sharan G., Prakash H. and Jadhav R. (2003). Performance of greenhouse coupled to earth tube heat exchanger in closed-loop mode. XXX CIOSTA-CIGR V Congress Proceedings of 'Management and Technology Applications to Empower Agriculture and Agro-food Systems,' Turin, Italy, Vol.2, September 22-24, pp.865-873.

21. Sharan, G. and Chitlange, V. (2004). "Characteristics of Some agronets in Visible Range," Research Note, Journal of Agricultural Engineering, 41:3, July-September 2004, pp.62-64.

22. Sharan, G and Jethva, K. (2008). "Cooling and Heating of Greenhouse in Arid Area by Earth Tube Heat Exchanger", Acta Horticulturae no 801, ISHS 200. 